\title{
Therapeutic Targeting of Histone Modifications in Adult and Pediatric High-Grade Glioma
}

\author{
Maria J. Williams ${ }^{1 *}$, Will G. B. Singleton ${ }^{2}$, Stephen P. Lowis ${ }^{3}$, Karim Malik ${ }^{4}$ and \\ Kathreena M. Kurian ${ }^{\text {* }}$ \\ ${ }^{1}$ Brain Tumour Research Group, Institute of Clinical Neurosciences, University of Bristol, Bristol, UK, ${ }^{2}$ Functional \\ Neurosurgery Research Group, Institute of Clinical Neurosciences, University of Bristol, Bristol, UK, ${ }^{3}$ Department of \\ Paediatric and Adolescent Oncology, Bristol Royal Hospital for Children, Bristol, UK, ${ }^{4}$ Cancer Epigenetics Laboratory, \\ Cellular and Molecular Medicine, University of Bristol, Bristol, UK
}

OPEN ACCESS

Edited by:

Kerrie Leanne McDonald, University of New South Wales,

Australia

Reviewed by:

David D. Eisenstat,

University of Alberta, Canada

Vinesh Puliyappadamba,

University of Alabama, USA

Maria Caffo,

University of Messina, Italy

*Correspondence:

Maria J. Williams

mw0470@my.bristol.ac.uk;

Kathreena M. Kurian

kathreena.kurian@bristol.ac.uk

Specialty section:

This article was submitted to Neuro-Oncology and Neurosurgical

Oncology,

a section of the journal

Frontiers in Oncology

Received: 02 March 2016 Accepted: 06 March 2017

Published: 28 March 2017

Citation:

Williams MJ, Singleton WGB, Lowis SP. Malik K and Kurian KM

(2017) Therapeutic Targeting of Histone Modifications in Adult and

Pediatric High-Grade Glioma.

Front. Oncol. 7:45.

doi: 10.3389/fonc.2017.00045
Recent exciting work partly through The Cancer Genome Atlas has implicated epigenetic mechanisms including histone modifications in the development of both pediatric and adult high-grade glioma (HGG). Histone lysine methylation has emerged as an important player in regulating gene expression and chromatin function. Lysine (K) 27 (K27) is a critical residue in all seven histone 3 variants and the subject of posttranslational histone modifications, as it can be both methylated and acetylated. In pediatric HGG, two critical single-point mutations occur in the H3F3A gene encoding the regulatory histone variant H3.3. These mutations occur at lysine (K) 27 (K27M) and glycine (G) 34 (G34R/N), both of which are involved with key regulatory posttranscriptional modifications. Therefore, these mutations effect gene expression, cell differentiation, and telomere maintenance. In recent years, alterations in histone acetylation have provided novel opportunities to explore new pharmacological targeting, with histone deacetylase (HDAC) overexpression reported in high-grade, late-stage proliferative tumors. HDAC inhibitors have shown promising therapeutic potential in many malignancies. This review focuses on the epigenetic mechanisms propagating pediatric and adult HGGs, as well as summarizing the current advances in clinical trials using HDAC inhibitors.

Keywords: glioblastoma multiforme, diffuse intrinsic brainstem glioma, histone methylation, histone acetylation, histone deacetylase inhibitors, epigenetics, high-grade glioma

\section{INTRODUCTION}

Recent exciting work partly through The Cancer Genome Atlas (TCGA), has implicated epigenetic mechanisms including histone modifications in the development of both pediatric and adult highgrade glioma (HGG). Importantly, epigenetic modifications have a potential for novel therapeutic drug targeting as epigenetic changes are catalyzed by highly specific enzyme complexes. For the purpose of this review, the term HGG is used to describe the astrocytic gliomas: anaplastic astrocytoma (WHO Grade III) and glioblastoma (WHO Grade IV) (1). The term diffuse intrinsic pontine glioma (DIPG) refers to a specific astrocytic glioma, which arises in the ventral pons in children who carries a uniformly fatal prognosis, with a median survival of 9 months (1). The annual incidence of adult glioblastoma is 7.2 per 100,000 , making it the most common adult primary intrinsic brain tumor (2). By contrast, in children, HGGs are reported to have an annual incidence of 0.8 per 100,000, 
representing $8-12 \%$ of pediatric central nervous system tumors and making them rare compared to other tumor types (2-4).

Unlike genetic abnormalities, epigenetic abnormalities encompass modifications that do not result from a change in the primary DNA sequence (5). These modifications include DNA methylation, histone methylation, and acetylation as well as other modifications that can indirectly regulate gene expression (5). A classic epigenetic modification in adult glioblastoma is DNA hypermethylation of the enzyme O-6-methylguanineDNA methyltransferase, which suppresses its normal function to remove alkyl groups from DNA (6). This makes such patients more sensitive to alkylating agents such as temozolomide (6).

Histones are positively charged proteins namely $\mathrm{H} 1, \mathrm{H} 2 \mathrm{~A}$, $\mathrm{H} 2 \mathrm{~B}, \mathrm{H} 3$, and $\mathrm{H} 4$, which make up the macromolecular threedimensional complex of chromatin together with negatively charged DNA (7). The nucleosome is the fundamental subunit of chromatin comprising a histone octamer with two copies of each of histones $\mathrm{H} 2 \mathrm{~A}, \mathrm{H} 2 \mathrm{~B}, \mathrm{H} 3$, and $\mathrm{H} 4$ (7). Histone $\mathrm{H} 3$ has seven known sequence variants in mammalian cells, which are highly sequence conserved, differing only by a few amino acids. These are histones H3.1, H3.2, H3.3, H3.4 (H3T), H3.5, H3.X, and H3.Y (8). Histone H3.3 has been shown to function in maintaining genome integrity during mammalian development, by supporting chromosomal chromatin structures (9). This histone variant is known to modulate specific chromatin changes and gene expression profiles and is often considered a mark of transcriptional activity (10).

Chromatin remodeling or modification represents a highly dynamic process in which there is continual laying down and removal of modifications by chromatin-remodeling enzymes resulting in three-dimensional changes, which can affect gene expression by regulating access to RNA polymerases and transcription factors (11). In particular, the $N$-terminal tails of histones contain lysine $(\mathrm{K})$ and arginine $(\mathrm{R})$ residues that can undergo posttranslational modifications including acetylation, methylation, ubiquitylation, and sumoylation, as well as serines that can be phosphorylated (11). These complex modifications affect almost all DNA-dependent processes, including gene expression, DNA replication and repair, and centromere and telomere maintenance $(11,12)$. Therefore, cross-talk between modifications may lead to myriad read-outs, which are beyond the scope of this review. We will therefore focus mainly on the posttranslational modification of histones by methylation and acetylation, as these are of current clinical interest in adults and pediatric HGG, and both processes are novel pharmacological targets with recent early phase clinical trials.

\section{HISTONE METHYLATION IN PEDIATRIC GLIOMA}

\section{H3F3A K27M and G34R/V Histone Mutations in Pediatric HGG}

Schwartzentruber et al. were the first to report recurrent mutations of a regulatory histone, $H 3 F 3 A$, in humans by exome sequencing of pediatric glioblastomas (see Figure 1) (13). The histone $\mathrm{H} 3 \mathrm{~F} 3 \mathrm{~A}$ encodes the histone variant $\mathrm{H} 3.3$, which is predominantly incorporated into transcription sites and telomeric regions, and is associated with active and open chromatin (14). Mutations in $\mathrm{H} 3 \mathrm{~F} 3 \mathrm{~A}$ involve two critical single-point mutations in the histone tail at lysine (K) $27(\mathrm{~K} 27 \mathrm{M})$ and glycine $(\mathrm{G}) 34(\mathrm{G} 34 \mathrm{R} / \mathrm{V})$, both of which are involved with key regulatory posttranscriptional modifications (13). As well as being reported in pediatric HGGs, H3.3 mutation are also reported in other childhood cancers such as chondroblastomas and giant cell tumors of the bone (15).

Histone lysine methylation has emerged as an important player in regulating gene expression and chromatin function. $\mathrm{K} 27$ is a critical residue in all seven histone 3 variants, and it can be posttranslationally methylated or acetylated (16). Acetylation may induce active transcription, while monomethylation, dimethylation or trimethylation of K27, catalyzed by the histone methyltransferase enhancer of zeste homologue 2 (EZH2), are repressive marks associated with gene silencing (5). The K27M mutation in certain cases results in decreased dimethylation and trimethylation of $\mathrm{H} 3 \mathrm{~K} 27$ and is associated with transcriptional activation; however, there are alternative mechanisms by which the $\mathrm{K} 27 \mathrm{M}$ increases trimethylation, thus silencing tumor suppressor gene expression (17). This occurs through bivalent domains, which occur on histone proteins and allow epigenetic regulators such as methylating enzymes to silence or activate gene expression (17). Similarly, the G34R/V mutation results in redistribution of $\mathrm{H} 3 \mathrm{~K} 36$ methylation and altered gene transcription, including upregulation of the MYCN (V-Myc avian myelocytomatosis viral oncogene neuroblastoma-Derived Homolog) oncogene $(13,18,19)$.

Importantly, $H 3 F 3 A$ mutations have been reported to have $100 \%$ specificity for pediatric HGGs, with no evidence of the mutations in pediatric low-grade gliomas, embryonal tumors, or ependymomas (20). Furthermore, several groups have reported that these histone H3.3 mutations are not identified in adult glioblastoma (20-22). Moreover, K27M and G34R/V mutations are associated with differing age and tumor location in childhood HGGs $(13,16,23)$. K27M histone H3.3 mutations occur more commonly in younger children (median age 10.5 years, range $5-23$ years) and are present in $70-80 \%$ of midline brainstem and thalamic glioblastoma $(13,16,23)$. G34R/V histone H3.3 mutations have been shown to occur more frequently in older children (median age 18 years, range $9-42$ years) and are observed almost exclusively in hemispheric gliomas $(16,23)$.

The K27M histone H3.3 mutation is associated with a shorter clinical survival $[0.73$ years $( \pm 0.48)](p=0.0008)$ compared with patients lacking the mutation $[4.59$ years $( \pm 5.55)]$. However, this poor survival may in part reflect the brainstem and midline locations of these pediatric gliomas (16).

\section{K27M Mutated Pediatric HGG, Polycomb Repressive Complex 2 (PRC2), and the Global Hypomethylator Phenotype}

The PRC2 is one of the two complexes of polycomb group proteins; the other component of this group of proteins is the polycomb repressive complex 1 (PRC1). Both PRC2 and PRC1 are often needed to maintain gene repression (24). PRC2 is required for the initial targeting of the genomic region [PRC response elements] 


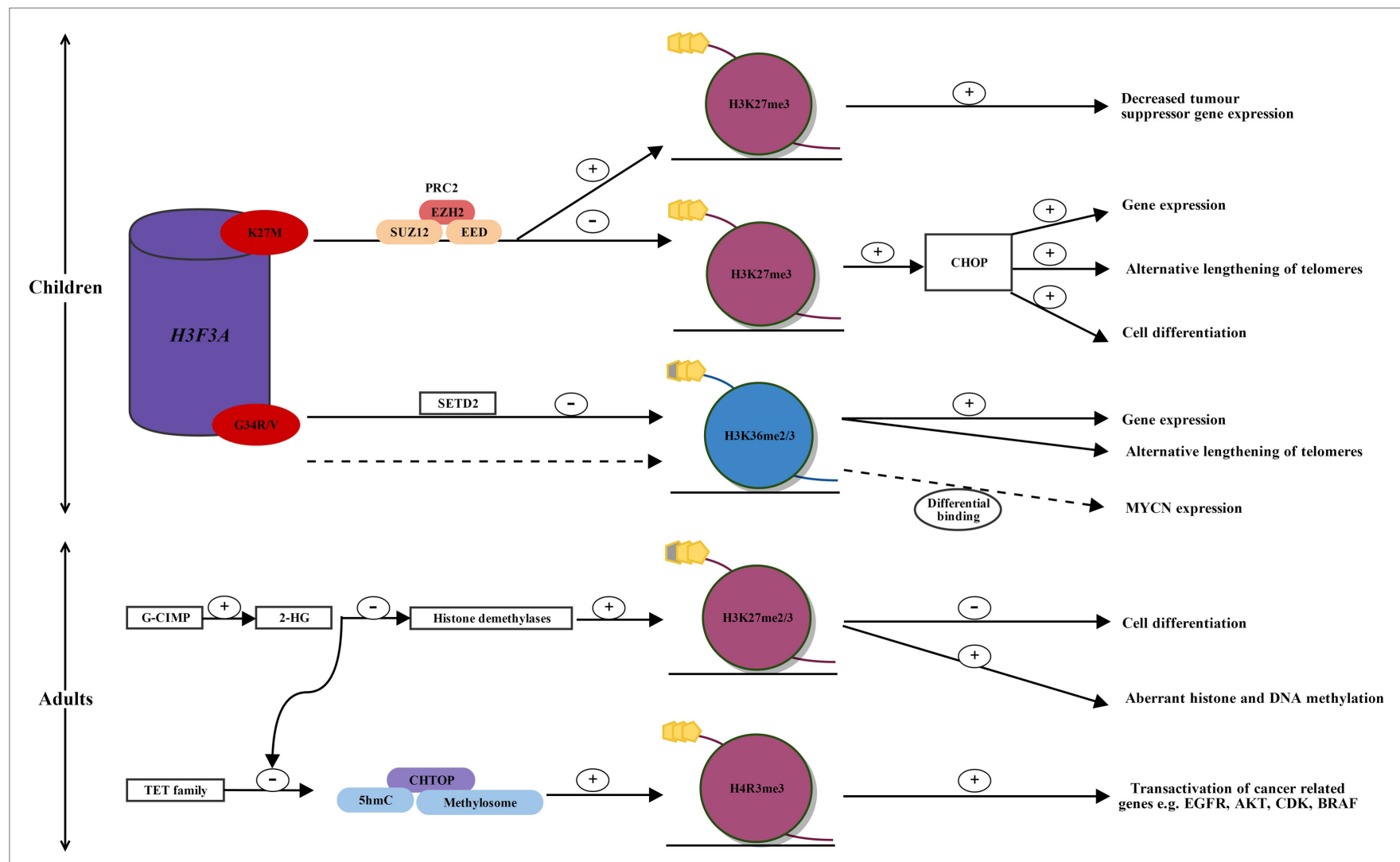

FIGURE 1 | Alterations in histone methylation in pediatric and adult high-grade glioma. In children, two single-point mutations in the regulatory histone, H3F3A, occur in the histone tail at $\mathrm{H} 3.3 \mathrm{~K} 27 \mathrm{M}$ and G34R/N, affecting key regulatory posttranscriptional modifications. H3.3 K27M mutated glioblastoma displays reprogramming of $\mathrm{H} 3 \mathrm{~K} 27$ methylation. $\mathrm{K} 27 \mathrm{M}$ alters the enzymatic activity of EZH2, the catalytic subunit of PRC2, which establishes H3K27 methylation. This leads to a global reduction in $\mathrm{H} 3 \mathrm{~K} 27$ methylation and the $\mathrm{CHOP}$, priming for increased gene expression, cell differentiation, and alternative lengthening of telomeres. Within a globally hypomethylated phenotype, K27M mutated glioma may allow increased H3K27 methylation at specific gene loci. An increased H3K27 methylation silences tumor suppressor gene expression, such as p16/NKA. In H3.3 G34R/V mutated glioma, mutations in SETD2 lead to decreased H3K36 methylation, which results in increased gene expression and alternative lengthening of telomeres. MYCN is upregulated through differential genomic binding of methylated $\mathrm{H} 3 \mathrm{~K} 36$ in G34R/V mutated glioblastoma. In adults, mutated IDH1 and induction of the G-CIMP phenotype lead to the overproduction of 2-HG. 2-HG inhibits histone demethylases leading to increased H3K27 methylation, which leads to a block in cell differentiation, and aberrant DNA and histone methylation. Over production of 2-HG also inhibits ten-eleven translocation (TET) activation, leading to a decrease in the $5 \mathrm{hmC} / \mathrm{CHTOP} /$ methylosome complex, which is normally present in wild-type IDH1 glioma. This results in decreased transactivation of cancer-related genes such as EGFR, AKT, CDK, and BRAF and may provide an explanation for increased survival in patients with IDH1 mutated glioblastoma. AKT, protein kinase B; BRAF, B-Raf proto-oncogene, serine/threonine kinase; CDK, cyclin-dependant kinase; CHOP, CpG hypomethylator phenotype; CHTOP, chromatin target of PRMT1; EGFR, epidermal growth factor receptor; EZH2, enhancer of zeste homologue 2; G-CIMP, glioma-CpG-island methylator phenotype; G34R/N, glycine34 arginine/valine; H3F3A, H3 histone family 3A; H3K27me2/3, histone 3 lysine 27 dimethylation/trimethylation; H4R3, histone 4 arginine 3; 2-HG, 2-hydroxyglutarate; 5hmC, 5-hyroxymethylcytosine; K27M, lysine 34 methionine; PRC2, polycomb repressive complex 2; SETD2, SET domain-containing 2; TET family, ten-eleven translocation family; +, increased; -, decreased; dotted line, alternative pathway in G34R/V mutated glioma.

to be silenced, while PRC1 is thought to work downstream of PRC2 and stabilizes the cellular memory of the silenced region after cellular differentiation (24).

The PRC2 complex has histone methyltransferase activity and silences gene expression by dimethylating or trimethylating H3K27 through its enzymatic subunits, enhancer of zeste homolog 1 and 2 (EZH1 and EZH2) $(24,25)$. Lewis et al. reported that PRC2 is inhibited by aberrant binding of mutant K27M to EZH2 (26). Moreover, K27M alters the enzymatic activity of EZH2, the catalytic subunit of PRC2, which establishes H3K27 methylation, thereby leading to a global reduction of $\mathrm{H} 3 \mathrm{~K} 27$ methylation and the loss of gene repression (see Figure 1) $(26,27)$.
Bender et al. used chromatin immunoprecipitation, nextgeneration sequencing, and whole-genome bisulfite sequencing on primary HGGs, to show reduced methylation of $\mathrm{H} 3 \mathrm{~K} 27$ primes generally for global DNA hypomethylation (28). This leads to the $\mathrm{CpG}$ hypomethylator phenotype (CHOP), resulting in the activation of gene expression and cell differentiation (see Figure 1) (28).

Subsequently, although mutant $\mathrm{K} 27 \mathrm{M}$ results in a global reduction of H3K27 methylation in HGGs, Chan et al. have reported that at specific gene loci there is a dramatic increase in $\mathrm{H} 3 \mathrm{~K} 27$ methylation, as well as an increase in the catalytic subunit of the PRC2 histone methyltransferase EZH2 $(17,29)$. Although 
DNA hypomethylation promotes gene expression, it would be disadvantageous to tumor cells if this included the expression of genes protecting against tumorigenesis, such as tumor suppressor genes. Therefore, Chan et al. have proposed that by inducing a globally hypomethylated phenotype (CHOP), this allows for increased binding of PRC2 and establishment of H3K27 methylation at specific gene loci (29). It is likely that tumor formation in H3.3 K27M mutated HGGs is driven by chromatin modifications occurring due to the loss and gain of $\mathrm{H} 3 \mathrm{~K} 27$ methylation at different gene loci (see Figure 1) (29). This correlates, for example, with a gain of $\mathrm{H} 3 \mathrm{~K} 27$ methylation at $16 I N K A 4 A$ and decreased expression of this tumor suppressor gene, consistent with promotion of tumorigenesis (see Figure 1) (29).

\section{Upregulation of MYCN in G34R/V Mutated Pediatric HGG}

By a similar mechanism to $\mathrm{H} 3 \mathrm{~K} 27$, histone $\mathrm{H} 3 \mathrm{~K} 36$ is also subject to alterations in methylation (30). Although still occurring in pediatric gliomas with mutations in the histone tail of $\mathrm{H} 3.3$, the mutation is G34R/V as opposed to K27M. Fontebasso et al. conducted whole exome sequencing on 60 pediatric HGGs and compared them to 543 non-cancer control samples (30). They showed that decreased methylation of H3K36 has been shown to occur through loss of function mutations in the $\mathrm{H} 3 \mathrm{~K} 36$ methyltransferase SET domain-containing 2 (30). The decrease in $\mathrm{H} 3 \mathrm{~K} 36$ trimethylation was shown to correlate with increased gene expression (30).

In addition, the G34R/V mutation was shown to upregulate MYCN, with increased RNA polymerase II binding and transcriptional upregulation at the gene locus, through the differential genomic binding of methylated $\mathrm{H} 3 \mathrm{~K} 36$ to specific gene loci (see Figure 1) $(19,31)$. MYCN is a potent oncogene implicated in many cancers, often signaling an aggressive and undifferentiated phenotype. Of recent discovery, forced overexpression of $M Y C N$ has been shown to cause glioblastoma in the developing mouse forebrain, providing evidence for a tumor-initiating event that may drive pediatric glioblastoma formation during neurological development $(19,32)$.

These insights provide opportunities for novel ways to target specific genetic and epigenetic aberrations in H3.3 G34R/V mutated pediatric HGGs.

\section{Putative Telomere Maintenance in G34R/V Mutated Pediatric HGG}

G34R/V mutations occurring in hemispheric pediatric HGG, frequently display mutations in TP53, ATRX ( $\alpha$-thalassemia/mental retardation syndrome X-linked), and $D A X X$ (death domainassociated protein), unlike the K27M mutated HGGs (13, 16, $23,33)$. Schwartzentruber et al. reported $100 \%$ of patients with H3.3 mutated G34R/V glioblastoma and who had mutations in $A T R X$ and DAXX, which encode two subunits required for $\mathrm{H} 3.3$ incorporation at centromeres and telomeres $(13,34,35)$.

Pathak et al. further investigated mutations in the H3.3-ATRXDAXX chromatin remodeling pathway in pediatric glioblastoma (36). They reported a global loss of histone methylation in $80 \%$ of cases, particularly a loss of trimethylation in histones H3K27 and
H3K4 (36). The combinatorial methylation loss of these histones was associated with $H 3 F 3 A-A T R X$ mutations, with $60 \%$ of $\mathrm{K} 27 \mathrm{M}$ cases and $75 \%$ of G34R mutant cases displaying ATRX loss (36).

H3F3A/ATRX-DAXX/TP53 mutations are strongly associated with alternative lengthening of telomeres, a telomeraseindependent telomere maintenance mechanism that could allow unlimited cellular proliferation in pediatric glioblastoma $(13,33$, $37,38)$.

\section{HISTONE METHYLATION IN ADULT GLIOMA}

\section{The Hypermethylator Phenotype Glioma- CpG-Island Methylator Phenotype (G-CIMP) Is Distinct from H3F3A Mutations, Occurring Rarely in Pediatric Glioma but More Frequently in Young Adults}

A high proportion of low-grade gliomas and secondary glioblastomas have been shown to harbor mutations in isocitrate dehydrogenase 1 and 2 (IDH1/IDH2) (see Figure 1) (39). IDH1 is an enzyme involved in the Krebs cycle of glucose metabolism (40). Its usual function is to decarboxylate isocitrate to yield $\alpha$-ketoglutarate (40). The mutation of IDH1 results in loss of normal enzymatic function and leads to the abnormal production of 2-hydroxyglutarate (2-HG) (40). 2-HG has been found to inhibit histone and DNA demethylases, causing widespread changes in histone and DNA methylation and potentially promoting tumorigenesis (40).

Although IDH1 mutations are relatively uncommon in pediatric glioblastoma, single amino acid substitutions of arginine result in gain of function mutations in $I D H 1$ [commonly arginine to histidine $(\mathrm{R} 132 \mathrm{H})$ ] and occur frequently in young adults with secondary glioblastoma, which has progressed from lower grade neoplasms $(41,42)$. IDH1 mutational status has been shown to be a positive prognosticator for survival in patients with glioblastoma. IDH1 indirectly affects $\mathrm{H} 3 \mathrm{~K} 27$ or H3K36 methylation by the oncometabolite 2-HG (43). 2-HG inhibits histone demethylases and is associated with a distinct G-CIMP, specifically increasing methylation of $\mathrm{H} 3 \mathrm{~K} 27$ and $\mathrm{H} 3 \mathrm{~K} 36$, which has been associated with a block in cell differentiation (see Figure 1) (43-45). Furthermore, the IDH1 mutations promoting methylation are associated with mutations in TP53 (13). This represents a third subgroup of pediatric and young adult glioblastoma, which is mutually exclusive from $H 3 F 3 A$ mutations (23). The importance of identifying $I D H 1$ mutation status is important for prognosis in this subgroup, with the opportunity to explore 2-HG inhibition and the potential to prevent the transformation of a low-grade malignancy to a HGG (43).

\section{Mutation-Independent Downregulation of H3.3 Favors Self-Renewal in Adult Glioblastoma Cancer Cells}

Recent breakthrough by Dirk et al. has provided a possible explanation for the paucity of $\mathrm{H} 3.3$ mutations in adult 
glioblastoma, by mutation-independent abnormalities in histone biology (46). By using patient-derived glioblastoma primary cultures that enrich for cells with tumor-initiating and self-renewal potential, they demonstrated that DNA methylation profiles in $H 3 F 3 A$ wild-type adult glioblastoma were similar to DNA methylation profiles of $\mathrm{H} 3.3$ mutated pediatric glioblastoma (46).

Mixed lineage leukemia 5 (MLL5) is the most divergent member of the MLL family. Its biological role is not fully characterized; however, it is known to lack methyltransferase function (47). To identify if epigenetic modifiers are implicated in the downregulation of H3.3 in adult glioblastoma, Dirk et al. investigated gene expression profiling across glioblastoma self-renewing cultures and found MLL5 to be expressed robustly (46). Overexpression of MLL5 in glioblastoma primary cultures led to decreased H3.3, while knockdown of MLL5 led to increased H3.3 protein, showing a direct role for MLL5 in repressing H3.3 (46). Furthermore, MLL5 overexpression led to increased expression of two chromatin condensing genes; therefore, MLL5 may exert transcriptional repression of $\mathrm{H} 3.3$ (via $H 3 F 3 B$ ) by altering chromatin configuration and accessibility (46).

Finally, histone demethylase inhibitors were tested in glioblastoma primary cultures and were shown to have potent suppressive effects of glioblastoma self-renewal (46). These findings suggest that chromatin remodeling could be exploited as a novel therapeutic target in adult glioblastoma.

\section{Overproduction of 2-HG Inhibits the Ten-Eleven Translocation (TET) Family and H3K27 Demethylases in Adult HGG}

Histone modifications occur less commonly in adults compared to children; however, mechanisms of glioma propagation have been explored with regards to H3K27 and histone 4 arginine 3 (H4R3) methylation. Epigenetic modifications of histone proteins occur through IDH1 mutation and induction of the G-CIMP phenotype (48). Subsequent overproduction of 2-HG inhibits the TET family of 5-hyroxymethylcytosine (5hmC) hydroxylases leading to a decrease in 5hmC (49). 2-HG also inhibits H3K27 demethylases leading to an increase in H3K27 methylation, with resulting aberrant histone and DNA methylation, as well as a block in cell differentiation (see Figure 1) $(43,45)$.

Taiki et al. showed that glioblastoma cells with wild-type IDH 1 contain increased TET and $5 \mathrm{hmC}$ levels, and TET- 1 production of $5 \mathrm{hmC}$ is required for gliomagenesis, by recruiting the chromatin target of PRMT1-methylosome complex (50). $5 \mathrm{hmC}$ has been previously reported to act as an intermediate for DNA demethylation but instead recruits DNA-binding proteins $(50,51)$. The methylosome is an arginine methyltransferase complex that promotes PRMT1-mediated methylation of H4R3 in genes involved in gliomagenesis, including EGFR, $A K T 3$, CDK6, CCND2, and BRAF (see Figure 1) (50). This provides a mechanism by which patients with mutated $I D H 1$ have a better survival compared to those with wild-type IDHI $(52,53)$.

\section{Histone Acetylation in Pediatric and Adult HGG-A Balancing Act between Histone Acetyltransferases (HATs) and Histone Deacetylases (HDACs)}

As well as undergoing methylation, histone tails can be also posttranslationally modified by acetylation (54). The balance of action between HATs and HDACs is a key regulatory mechanism in the transcriptional activation and repression of gene expression, respectively (54). HDACs are overexpressed in many cancers, and targeting with HDAC inhibitors has provided a promising avenue in the development of new therapeutic approaches (55). HDACs facilitate the condensation of chromatin, by removing acetyl groups from the $\mathrm{N}$-terminal tails of histone proteins, preventing the access of transcriptional machinery to DNA, and by binding of SWI3, ADA2, N-CoR and TFIIIB (SANT) containing proteins (56). SANT containing proteins bind unacetylated proteins, inhibiting HATs and facilitating HDAC binding (54, 56). There are 18 HDAC enzymes, and these are classified as zinc dependent (class I, IIa, IIb, and IV) or zinc independent and NAD dependent (class III) (55). It is particularly class I and II HDACs, which have become the focus for targeting as anticancer therapies (55). Class I HDACs associate with multiprotein complex repressors and have a role in cell survival and proliferation (55, 57-60). Class IIa HDACs have tissue-specific roles, and class IIb HDACs have been identified in the regulation of cell survival in response to stress $(58,61)$. There are non-histone protein targets of HDACs, including hormone receptors, transcription factors, and DNA repair enzymes $(60,62)$. The recent advances in the targeting of HDACs with HDAC inhibitors is therefore a complex process due to the lack of HDAC inhibitor specificity for histone proteins and little understanding of their mechanism of action $(60,62,63)$.

\section{Altered Expression of HDACs in Adult and Pediatric Glioblastoma}

The Cancer Genome Atlas used genome-wide sequencing of 284 glioblastoma samples to identify somatic mutations in genes involved with histone modifications and identified somatic mutations in HDAC2 (64).

Lucio-Etevoric et al. evaluated mRNA expression of class I, II, and IV HDACs in 20 low-grade gliomas (13 grade I and 7 grade II) and 23 HGGs (5 grade III and 18 glioblastomas), with patient ages ranging from 1.3 to 79 years (mean age 24.6 years, SD of $12.8 \pm 22.6$ years) (65). They reported hypoexpression of HDACs II and IV in glioblastoma compared to low-grade gliomas and normal brain tissue (65). In contrast, HDAC I overexpression has been reported in high-grade, late-stage proliferative tumors, supporting the rationale for the use of HDAC inhibitors in promoting the re-expression of silenced tumor suppressor genes in glioblastoma, as well as a more open chromatin structure facilitating access for DNA damaging agents $(66,67)$. Therefore, HDACs may have a role in repressing genes associated with gliomagenesis, and HDAC inhibitors may not be effective in all cases of glioblastoma, as they may potentiate the transcriptional activation of proto-oncogenes $(65,68)$. 


\section{PHARMACOLOGICAL TARGETING OF HISTONE MODIFIERS IN HGG}

\section{Pediatric HGG Trials Using HDAC Inhibitors}

Tables 1 and 2 summarize completed phase I and phase II trials investigating the use of HDAC inhibitors, in pediatric and adult gliomas. The Children's Oncology Group has conducted two trials investigating the use of the pan-HDAC inhibitor vorinostat as a therapy for pediatric HGG $(69,70)$. They investigated vorinostat administered singly or in combination 13-cis retinoic acid (isotretinoin) in children with refractory solid tumors (69). They showed the maximum tolerated dose (MTD) of vorinostat was $230 \mathrm{mg} / \mathrm{m}^{2} /$ dose as a single agent or $180 \mathrm{mg} / \mathrm{m}^{2} /$ dose $4 \times$ per week with and $13 \mathrm{cRA} 80 \mathrm{mg} / \mathrm{m}^{2} /$ dose $2 \times$ daily, days $1-14$ every 28 days (69). Dose-limiting toxicities for vorinostat as a single agent included neutropenia, thrombocytopenia, and hypokalemia (69). Dose-limiting toxicities for vorinostat and $13 \mathrm{cRA}$ included neutropenia, thrombocytopenia, anorexia, and hypertriglyceridemia (69). Prolonged stable disease was observed in five patients including one of seven with DIPG, and a complete response was observed in one patient with neuroblastoma (69).

A second phase I study by the Children's Oncology Group investigated vorinostat with the alkylating agent temozolomide in relapsed or refractory primary CNS tumors and showed that $300 \mathrm{mg} / \mathrm{m}^{2} /$ day of vorinostat in combination with $150 \mathrm{mg} / \mathrm{m}^{2} /$ day of temozolomide is well tolerated in 5-day cycles every 28 days (70). Myelosuppression was the major dose-limiting toxicity (70). Stable disease was observed in one of seven patients with HGG (70). An ongoing phase I/II trial for newly diagnosed glioblastoma is investigating vorinostat with radiotherapy and concomitant temozolomide (71).

A further phase I trial conducted by the Children's Oncology Group investigated vorinostat in combination with bortezomib, a selective inhibitor of the ubiquitin-proteasome pathway, in children with recurrent or refractory solid tumors (72). This showed a MTD of vorinostat $230 \mathrm{mg} / \mathrm{m}^{2} /$ day on days $1-5$ and $8-12$ of a 21 -day cycle and bortezomib $1.3 \mathrm{mg} / \mathrm{m}^{2}$ on days $1,4,8$, and 11 of the same cycle (72). Dose-limiting toxicities included sensory neuropathy, nausea, and anorexia (72). Six of twentythree patients had a malignant glioma; no objective response was observed in any of the patients (72).

The Children's Oncology Group has also conducted a phase I trial investigating the HDAC inhibitor valproic acid in children with refractory solid or CNS tumors (73). They showed that valproic acid administered three times daily to maintain trough concentrations of $75-100 \mu \mathrm{g} / \mathrm{mL}$ was well tolerated by patients. No dose-limiting toxicities were observed at this dose. Of four patients with DIPG, one patient (glioblastoma) was observed to have a confirmed partial response and one patient (DIPG) was observed to have a minor response (73).

Ongoing clinical trials are investigating event-free survival in children with newly diagnosed HGGs and brainstem gliomas, using valproic acid with radiotherapy, followed by bevacizumab (74). A phase II/III trial is ongoing having recruited children with HGG and is studying the event-free survival using vorinostat, or temozolomide, or bevacizumab in combination with radiotherapy, followed by treatment with bevacizumab and temozolomide (75).

\section{Adult HGG Trials Using HDAC Inhibitors}

The North Central Cancer Treatment Group has conducted two phase II trials looking at vorinostat as a treatment for glioblastoma $(76,77)$. The first trial using vorinostat as a single agent found that it had modest activity in patients with recurrent glioblastoma (76). A cohort of 66 patients was treated, and median overall survival from study entry was 5.7 months (range $0.7-28+$ months) with a median time to progression of 1.9 months (range $0.3-28+$ months). Interestingly, $15 \%$ of patients were progression free at 6 months, and their duration of disease stability was long with a median of 11.2 months (range 6.8-28+ months) (76). This study revealed a subpopulation who benefit from HDAC inhibitor therapy, with the potential to investigate vorinostat in combination with other therapies, as well as its effect on newly diagnosed glioblastoma (76).

The second trial by the North Central Cancer Treatment Group investigated vorinostat in combination with the proteasome inhibitor bortezomib, in patients with recurrent glioblastoma (77). Unfortunately, in this trial, the progression-free survival at 6 months was $0 \%$, median time to progression was 1.5 months (range $0.5-5.6$ months), and median overall survival was 3.2 months (77). Therefore, this combination was not recommended for further investigation in patients with recurrent glioblastoma (77).

A phase I/II trial using the HDAC inhibitor romidepsin was conducted by the North American Brain Tumor Consortium for adults with recurrent malignant glioma (78). Thirty-five patients with recurrent glioblastoma were entered to the study, and the median overall survival was 34 weeks (95\% CI, 21-47 weeks) (78). This showed that there was no significant clinical activity of romidepsin as a single agent in unselected patients with recurrent glioblastoma, and so it was concluded to be ineffective (78).

Panobinostat is an HDAC inhibitor with anti-angiogenic activity and has been tested in a phase I trial with the anti-VEGF monoclonal antibody bevacizumab, in patients with recurrent HGG (79). The recommended doses were oral panobinostat $30 \mathrm{mg}$ three times per week, every other week, with bevacizumab $10 \mathrm{mg} / \mathrm{kg}$ every other week (79). The major dose-limiting toxicity was thrombocytopenia (79). The trial was escalated to phase II for patients with recurrent glioblastoma and recurrent anaplastic glioma; however, of 24 patients with glioblastoma, median overall survival was 9 months (range 6-19 months), and the glioblastoma cohort of the trial was closed at interim analysis (80). The trial was completed in anaplastic glioma patients, with a median overall survival of 17 months (range 5-27 months) (80). Panobinostat in combination with bevacizumab was concluded to be no more effective than bevacizumab alone; this is hypothesized to be due to diminished transport of panobinostat and bevacizumab across the blood-brain barrier (80). Preclinical evidence has shown that panobinostat may act as a radiosensitizer, and recently, a phase 1 trial combining panobinostat with stereotactic re-irradiation in patients with recurrent HGG has been reported (81). The results were more promising than panobinostat with bevacizumab, with 
TABLE 1 | Summary of completed phase I clinical trials investigating histone deacetylase inhibitors for the treatment of adult and pediatric high grade glioma.

\begin{tabular}{|c|c|c|c|c|c|c|}
\hline \multirow[t]{2}{*}{ Clinical trial } & \multirow[t]{2}{*}{ Phase } & \multirow[t]{2}{*}{ Population } & \multicolumn{2}{|l|}{ Results } & \multirow[t]{2}{*}{ Clinical observations } & \multirow[t]{2}{*}{ Reference } \\
\hline & & & Maximum tolerated dose & Dose-limiting toxicities & & \\
\hline $\begin{array}{l}\text { Vorinostat or vorinostat } \\
\text { and 13-cis retinoic acid }\end{array}$ & I & $\begin{array}{l}\text { Pediatric: Refractory } \\
\text { solid tumors or } \\
\text { leukemias }\end{array}$ & $\begin{array}{l}\text { Vorinostat } 230 \mathrm{mg} / \mathrm{m}^{2} / \text { dose and vorinostat } 180 \mathrm{mg} / \mathrm{m}^{2} / \text { dose } 4 \times \text { per week } \\
\text { and } 13 \mathrm{cRA} 80 \mathrm{mg} / \mathrm{m}^{2} / \text { dose } 2 \times \text { daily, days } 1-14 \text { every } 28 \text { days }\end{array}$ & $\begin{array}{l}\text { Single agent: neutropenia, } \\
\text { thrombocytopenia, and } \\
\text { hypokalemia } \\
\text { Combination therapy: } \\
\text { thrombocytopenia, } \\
\text { neutropenia, anorexia, and } \\
\text { hypertriglyceridemia }\end{array}$ & $\begin{array}{l}\text { Prolonged stable disease in } 1 / 7 \\
\text { with diffuse intrinsic pontine } \\
\text { glioma (DIPG) }\end{array}$ & (62) \\
\hline $\begin{array}{l}\text { Vorinostat and } \\
\text { temozolomide }\end{array}$ & । & $\begin{array}{l}\text { Pediatric: Relapsed or } \\
\text { refractory primary brain } \\
\text { or spinal cord tumors }\end{array}$ & $\begin{array}{l}\text { Vorinostat } 300 \mathrm{mg} / \mathrm{m}^{2} / \text { day and temozolomide } 150 \mu \mathrm{g} / \mathrm{m}^{2} / \text { day, } 5 \text {-day } \\
\text { cycles every } 28 \text { days }\end{array}$ & Myelosuppression & $\begin{array}{l}\text { Stable disease in } 1 / 7 \text { with high- } \\
\text { grade glioma (HGG) }\end{array}$ & (63) \\
\hline Valproic acid & । & $\begin{array}{l}\text { Pediatric: Refractory } \\
\text { solid or CNS tumors }\end{array}$ & Valproic acid $3 \times$ daily to maintain rough concentrations of $75-100 \mu \mathrm{g} / \mathrm{mL}$ & None & $\begin{array}{l}\text { Response in } 2 / 4 \text { with DIPG (1 } \\
\text { partial and } 1 \text { minor) }\end{array}$ & (66) \\
\hline $\begin{array}{l}\text { Vorinostat and } \\
\text { bortezomib }\end{array}$ & I & $\begin{array}{l}\text { Pediatric: Refractory or } \\
\text { recurrent solid tumors } \\
\text { (6/23 malignant glioma) }\end{array}$ & $\begin{array}{l}\text { Vorinostat } 230 \mathrm{mg} / \mathrm{m}^{2} / \text { day, days } 1-5 \text { and } 8-12 \text { of } 21 \text {-day cycle, } \\
\text { bortezomib } 1.3 \mathrm{mg} / \mathrm{m}^{2} / \text { day on days } 1,4,8 \text {, and } 11 \text { of a } 21 \text {-day cycle }\end{array}$ & $\begin{array}{l}\text { Sensory neuropathy, nausea, } \\
\text { anorexia }\end{array}$ & No objective responses observed & (65) \\
\hline $\begin{array}{l}\text { Panobinostat and } \\
\text { bevacizumab }\end{array}$ & । & Adult: Recurrent HGG & $\begin{array}{l}\text { Panobinostat } 30 \mathrm{mg} 3 \times \text { per week, every other week, with bevacizumab } \\
10 \mathrm{mg} / \mathrm{kg} \text { every other week }\end{array}$ & None & $\begin{array}{l}3 / 12 \text { partial response, } 7 / 12 \text { stable } \\
\text { disease }\end{array}$ & (72) \\
\hline $\begin{array}{l}\text { Vorinostat, bevacizumab } \\
\text { and irinotecan }\end{array}$ & । & $\begin{array}{l}\text { Adult: Recurrent } \\
\text { glioblastoma }\end{array}$ & Vorinostat $400 \mathrm{mg}$ twice daily on days $1-3$ and $15-17$, every 28 days & $\begin{array}{l}\text { Fatigue, hypertension/ } \\
\text { hypotension, and central } \\
\text { nervous system ischemia }\end{array}$ & Overall survival 7.3 months & (83) \\
\hline $\begin{array}{l}\text { Vorinostat and } \\
\text { isotretinoin, or vorinostat } \\
\text { and isotretinoin and } \\
\text { carboplatin }\end{array}$ & I & $\begin{array}{l}\text { Adult: Recurrent } \\
\text { malignant glioma }\end{array}$ & $\begin{array}{l}\text { Vorinostat } 400 \mathrm{mg} / \text { day, days } 1-14 \text {, isotretinoin } 100 \mathrm{mg} / \mathrm{m}^{2} / \text { day, days } \\
1-21 \\
\text { Carboplatin excessive toxicity, replaced with temozolomide. Vorinostat } \\
500 \mathrm{mg} / \text { day, days } 1-7 \text { and } 15-21 \text {, isotretinoin } 100 \mathrm{mg} / \mathrm{m}^{2} / \text { day, days } \\
1-21 \text {, temozolomide } 150 \mathrm{mg} / \mathrm{m}^{2} / \text { day, days } 1-7 \text { and } 15-21\end{array}$ & $\begin{array}{l}\text { Elevated AST, } \\
\text { hypertriglycidemia } \\
\text { None }\end{array}$ & $\begin{array}{l}\text { Progression-free survival at } \\
6 \text { months in 10/55 patients }(7 / 10 \\
\text { had glioblastoma) }\end{array}$ & (84) \\
\hline $\begin{array}{l}\text { Panobinostat with } \\
\text { fractionated stereotactic } \\
\text { re-irradiation therapy }\end{array}$ & I & Adult: HGG & $\begin{array}{l}\text { Panobinostat } 30 \mathrm{mg} 3 \times \text { weekly during radiotherapy. Radiation dose was } \\
35 \text { in } 3.5 \text { Gy fractions given over } 2 \text { weeks }\end{array}$ & $\begin{array}{l}\text { Thrombocytopenia, } \\
\text { neutropenia, prolonged QTC }\end{array}$ & $\begin{array}{l}\text { Progression-free survival at } \\
6 \text { months in } 30 \mathrm{mg} \text { cohort, } 5 / 6 \\
\text { patients. Median overall survival } \\
\text { in } 30 \mathrm{mg} \text { cohort } 16.1 \text { months }\end{array}$ & (74) \\
\hline $\begin{array}{l}\text { Vorinostat and } \\
\text { temozolomide }\end{array}$ & I & Adult: HGG & $\begin{array}{l}\text { Vorinostat } 500 \mathrm{mg} \text { days } 1-7 \text { and } 15-21 \text { of every } 28 \text {-day cycle in } \\
\text { combination with temozolomide } 150 \mathrm{mg} / \mathrm{m}^{2} / \text { day days } 1-5 \text { of every } 28 \text {-day } \\
\text { cycle }\end{array}$ & $\begin{array}{l}\text { Anorexia, alternative } \\
\text { lengthening of telomeres } \\
\text { rise, thrombocytopenia, } \\
\text { hemorrhage }\end{array}$ & Not specified & (85) \\
\hline
\end{tabular}

Pediatric: Refractory

solid tumors or

Vorinostat $230 \mathrm{mg} / \mathrm{m}^{2} /$ dose and vorinostat $180 \mathrm{mg} / \mathrm{m}^{2} /$ dose $4 \times 1$.

Combination th

hypertriglyceridemia 
TABLE 2 | Summary of phase II clinical trials investigating histone deacetylase inhibitors in pediatric and adult high-grade glioma (HGG).

\begin{tabular}{|c|c|c|c|c|c|c|}
\hline Clinical trials & Phase & Population & Drug regimen & Side effects & Results & Reference \\
\hline Panobinostat & $\|$ & Adult: Recurrent HGG & $\begin{array}{l}\text { Panobinostat } 30 \mathrm{mg} 3 \times \text { per week, every other week, with } \\
\text { bevacizumab } 10 \mathrm{mg} / \mathrm{kg} \text { every other week }\end{array}$ & $\begin{array}{l}\text { Bone marrow toxicity and } \\
\text { hypophosphatemia }\end{array}$ & $\begin{array}{l}\text { Glioblastoma arm closed at interim analysis, median } \\
\text { overall survival } 9 \text { months (range 6-19 months). } \\
\text { Anaplastic glioma arm to completion, median overall } \\
\text { survival } 17 \text { months (range } 5-27 \text { months) }\end{array}$ & (73) \\
\hline Vorinostat & $\|$ & $\begin{array}{l}\text { Adult: Recurrent } \\
\text { glioblastoma, receiving } \\
\leq 1 \text { chemotherapy } \\
\text { regimes for progressive } \\
\text { disease }\end{array}$ & $200 \mathrm{mg} 2 \times$ daily for 14 days, then 7 -day rest & $\begin{array}{l}\text { Thrombocytopenia, fatigue, } \\
\text { hyponatremia, dehydration }\end{array}$ & $\begin{array}{l}\text { Median overall survival } 5.7 \text { months (range } \\
0.7-28+\text { months), } 9 / 52 \text { patients progression free } \\
\text { at } 6 \text { months with median duration of stable disease } \\
11.2 \text { months (range } 6.8-28+\text { months) }\end{array}$ & (69) \\
\hline $\begin{array}{l}\text { Vorinostat and } \\
\text { bortezomib }\end{array}$ & $\|$ & $\begin{array}{l}\text { Adult: Recurrent } \\
\text { glioblastoma }\end{array}$ & $\begin{array}{l}400 \mathrm{mg} \text { daily for } 14 \text { days of a } 21 \text {-day cycle, } 1.3 \mathrm{mg} / \\
\mathrm{m}^{2} \text { bortezomib days } 1,4,8 \text {, and } 11\end{array}$ & $\begin{array}{l}\text { Bone marrow toxicity, } \\
\text { fatigue, neuropathy }\end{array}$ & $0 / 34$ progression free at 6 months & (70) \\
\hline Romidepsin & $1 / 11$ & Adult: Recurrent HGG & $13.3 \mathrm{mg} / \mathrm{m}^{2} /$ day on days 1,8 , and 15 of each 28 -day cycle & $\begin{array}{l}\text { Bone marrow toxicity and } \\
\text { fatigue }\end{array}$ & $\begin{array}{l}\text { Median overall survival } 34 \text { weeks ( } 95 \% \text { confidence } \\
\text { interval 21-47 weeks) }\end{array}$ & (71) \\
\hline $\begin{array}{l}\text { Radiotherapy with } \\
\text { temozolomide and } \\
\text { valproic acid }\end{array}$ & $\|$ & $\begin{array}{l}\text { Adult: Newly diagnosed } \\
\text { glioblastoma }\end{array}$ & $\begin{array}{l}\text { Valproic acid, } 25 \mathrm{mg} / \mathrm{kg}, 2 \times \text { daily. First valproic acid dose } \\
1 \text { week before the first day of radiotherapy at } 10-15 \mathrm{mg} / \mathrm{kg} / \\
\text { day }\end{array}$ & $\begin{array}{l}\text { Bone marrow toxicity, } \\
\text { neurological toxicity, } \\
\text { metabolic toxicity }\end{array}$ & $\begin{array}{l}\text { Median overall survival } 29.6 \text { months (range } \\
21-63.8 \text { months) }\end{array}$ & (75) \\
\hline $\begin{array}{l}\text { Vorinostat, } \\
\text { temozolomide, } \\
\text { and radiotherapy }\end{array}$ & $1 / 11$ & $\begin{array}{l}\text { Adult: Newly diagnosed } \\
\text { glioblastoma }\end{array}$ & $\begin{array}{l}\text { Vorinostat } 300 \mathrm{mg} / \text { day, days } 1-5 \text { weekly during radiotherapy } \\
\text { and with temozolomide, after } 4-6 \text { weeks break, up to } 12 \\
\text { cycles of vorinostat } 400 \mathrm{mg} / \text { day, days } 1-7 \text { and } 15-21 \text { with } \\
\text { temozolomide }\end{array}$ & $\begin{array}{l}\text { Neutropenia, } \\
\text { thrombocytopenia and } \\
\text { lymphopenia }\end{array}$ & $\begin{array}{l}\text { Time to progression } 8.05 \text { months ( } 95 \% \text { confidence } \\
\text { interval 6.21-9.30) }\end{array}$ & (64) \\
\hline $\begin{array}{l}\text { Vorinostat, } \\
\text { bevacizumab, and } \\
\text { temozolomide }\end{array}$ & $\mid / I I$ & $\begin{array}{l}\text { Adult: Recurrent } \\
\text { malignant glioma }\end{array}$ & $\begin{array}{l}\text { Vorinostat } 400 \mathrm{mg} / \text { day, days } 1-7 \text { and } 15-21 \text { of each } \\
28 \text {-day cycle, temozolomide daily dosing at } 50 \mathrm{mg} / \mathrm{m}^{2} / \text { day, } \\
\text { bevacizumab } 10 \mathrm{mg} / \mathrm{kg} \text { every other week starting day } 1\end{array}$ & $\begin{array}{l}\text { Bone marrow toxicity, } \\
\text { seizure, venous } \\
\text { thromboembolism }\end{array}$ & $\begin{array}{l}\text { Median overall survival } 12.5 \text { months ( } 95 \% \text { confidence } \\
\text { interval 8.8-14.3 months) }\end{array}$ & (82) \\
\hline
\end{tabular}


a progression-free survival at 6 months of $83 \%$ in the panobinostat and stereotactic re-irradiation therapy group, compared to $30.4 \%$ in the panobinostat with bevacizumab group $(80,81)$. It would be interesting to investigate this further via a phase II trial and assess the efficacy of the synergistic relationship between panobinostat and fractionated stereotactic re-irradiation therapy.

Valproic acid is an antiepileptic drug with HDAC inhibitor activity. A phase II trial investigated concurrent radiotherapy, temozolomide, and valproic acid in 37 patients with newly diagnosed glioblastoma (82). Median overall survival was 29.6 months (range 21-63.8 months) (82). Compared to five other phase II trials investigating radiotherapy and temozolomide with radiation modifiers including erlotinib, enzastaurin, and poly-ICLC, this result shows a large increase in overall survival, with the other studies showing overall survivals from 8.6 to 9.3 months (83-87). This observation is further supported by a retrospective study conducted by Weller et al. Patients with glioblastoma receiving radiotherapy alone or radiotherapy with temozolomide were analyzed to investigate the effect of antiepileptic therapy given during this treatment time (88). They found the overall survival was similar for patients taking an antiepileptic drug versus those who were not, except for those taking the HDAC inhibitor valproic acid (88). Patients taking valproic acid had a better overall survival benefit from radiotherapy with temozolomide (hazard ratio $0.39,95 \%$ confidence interval $0.24-0.63$ ), compared to those taking another antiepileptic drug or no antiepileptic drug (88).

A phase I/II trial investigated the efficacy of vorinostat in combination with bevacizumab and daily temozolomide in recurrent glioblastoma (89). Dose-limiting toxicities included bone marrow toxicity, hyperglycemia, pulmonary embolism, bowel perforation, and intracranial hematoma (89). The 6-month progression-free survival was $52.4 \%$ (95\% CI, 36.4-66.1\%) (89). The best radiographic responses were 2 complete responses, 17 partial responses, and 20 stable responses, with 1 radiographic progression (89). This trial provides promising insight into the efficacy of bevacizumab, temozolomide, and vorinostat on recurrent glioblastoma with reasonable toxicity (89).

Histone deacetylase inhibitors as a monotherapy for HGGs seem disappointing; however, the latest trials investigating HDAC inhibitors as part of a combination therapy seem promising in improving prognosis in this difficult to treat malignancy, with further ongoing studies that are yet to be published (81, 90-92).

\section{FUTURE DIRECTIONS}

\section{Histone Demethylase Inhibition in Experimental Models}

With increasing knowledge of oncogenic epigenetic changes underlying HGGs, such as the H3.3 K27M mutation, targeting to reverse these changes has been explored, although to date the field is far less advanced than HDAC inhibition. Hashizume et al. explored inhibiting JMJD3, the H3K27 demethylase, with GSKJ4 as a therapeutic strategy for pediatric HGG (93). By increasing H3K27 methylation, this could inhibit gene expression that would drive gliomagenesis, as well as blocking cell differentiation (94). H3.3 K27M glioma cell lines showed 50\% growth reduction, more apoptosis, and complete inhibition of clonal growth with
GSKJ4 treatment, while JMJD3 depleted glioma cell lines showed no significant reduction in proliferation $(93,94)$. In athymic (nu/ nu genotype, BALB/c background) mice with brainstem K27M glioma xenografts, GSKJ4 treatment resulted in significant tumor growth reduction and extended survival $(93,94)$.

\section{Combination Therapy Is Synergistic}

With the knowledge of H3.3 mutations and subsequent aberrant histone methylation, a recent study by Grasso et al. has investigated the use of the pan-HDAC inhibitor panobinostat, with the histone demethylase inhibitor GSKJ4 (95). They used a panel of 14 patient-derived DIPG cell cultures, obtained from both biopsy and autopsy samples (95). Western blot analyses of cells expressing the H3.3 K27M mutation showed that following panobinostat treatment, there was an increase in $\mathrm{H} 3$ acetylation and $\mathrm{H} 3 \mathrm{~K} 27$ methylation, suggesting there is a partial rescue of the H3.3 K27M-induced global hypomethylator phenotype CHOP (95). Furthermore, they showed that panobinostat was synergistic with GSKJ4 in decreasing cell viability of the H3.3 K27M mutant DIPG cells (95). This presents an exciting option to target histone methylation and acetylation in clinical trials with the hope of combating HGGs.

As well as targeting HDAC inhibition, EZH2 inhibition provides an alternative mechanism to prevent aberrant histone methylation of target genes, which may promote cell differentiation and prevent cell proliferation in several tissues (96). This has been demonstrated by preclinical studies in pediatric rhabdomyosarcoma (97). By using pharmacological inhibition of EZH2, the aggressiveness of rhabdomyosarcoma is less with a more differentiated phenotype (97). This provides further treatment options for rhabdomyosarcoma by using EZH2 inhibitors as adjuvant therapy, thus with a likely possibility of increasing the effectiveness of current conventional treatment (97). EZH2 overexpression is reported in many malignancies including lymphoma, breast cancer, and prostate cancer (98-100). Phase I pediatric and phase II adult clinical trials are underway to investigate the efficacy of EZH2 inhibitors in hematological malignancies, as well as genetically defined solid tumors, including mesothelioma and malignant rhabdoid tumors (ClinicalTrials.gov identifier: NCT 02601937 and NCT 02601950).

Although this review has focused predominantly on aberrations in histone H3K27 methylation, aberrations in methylation and acetylation of other histone proteins may provide positive or negative prognostic indicators for patients with glioma. Liu et al. reported the relationship between multiple histone modifications and patient prognosis (101). They analyzed by recursive partitioning analysis, a retrospective cohort of patients with HGG, with progression-free survival and overall survival as the primary end points (101). Immunohistochemical analysis of $\mathrm{H} 3 \mathrm{~K} 4$, H4R3, H4K20, H3K9, H3K18, H4K12, and H4K16 from 230 surgical HGG specimens suggested that lower levels of histone H3K4 methylation were associated with poor prognosis (101). In contrast to this, they found lower levels of histone acetylation in H3K18 were associated with a more favorable survival (101). This study highlights the potential prognostic impact of epigenetic changes in patients with HGG. This may provide future direction in selecting patients for optimal adjuvant treatment. 
Finally, the targeting of genetic mutations in combination with epigenetic aberrations may increase the likelihood of successfully treating adult and pediatric HGG. Taylor et al. identified $21 \%$ of pediatric DIPG harbored heterozygous somatic coding mutations in the gene $A C V R 1$, which encodes the activin A type I receptor serine/threonine kinase ALK2 (102). ACVR1 mutations were found to cosegregate with histone H3.1 K27M mutated DIPG (102). Previously, in patients with the autosomal dominant congenital childhood developmental disorder fibrodysplasia ossificans progressiva, identical ACVR1 mutations have been shown to constitutively activate the bone morphogenic protein (BMP)-dependent transforming growth factor- $\beta$ pathway (103). The results of this study suggest a role for BMP inhibitors to target one of the possible mechanisms driving tumorigenesis in DIPG (102). Future trials would be of interest to see the efficacy of BMP inhibitors singly or in combination with epigenetic targeting therapies such as HDAC or EZH2 inhibitors.

\section{Limitations of Therapeutic Targeting of Epigenetics in HGG}

The discovery of aberrant histone modifications propagating gliomagenesis has allowed the exploration of HDAC inhibitors and histone demethylase inhibitors in an attempt to combat an aggressive brain tumor. Current limitations of epigenetic targeting remain a challenge; in particular, the mechanism of HDAC inhibitors and their effect on cellular signaling pathways remains to be elucidated, and the effects of broadly altering functional epigenetic changes is unpredictable. Furthermore, there is

\section{REFERENCES}

1. Louis DN, Ohgaki H, Wiestler OD, Cavenee WK, Burger PC, Jouvet A, et al. The 2007 WHO classification of tumours of the central nervous system. Acta Neuropathol (2007) 114(2):97-109. doi:10.1007/s00401-0070243-4

2. Ostrom QT, Gittleman H, Liao P, Rouse C, Chen Y, Dowling J, et al. CBTRUS statistical report: primary brain and central nervous system tumors diagnosed in the United States in 2007-2011. Neuro Oncol (2014) 16(Suppl 4):iv1-63. doi:10.1093/neuonc/nou223

3. Fangusaro J. Pediatric high grade glioma: a review and update on tumor clinical characteristics and biology. Front Oncol (2012) 2:105. doi:10.3389/ fonc.2012.00105

4. Broniscer A. Past, present, and future strategies in the treatment of high-grade glioma in children. Cancer Invest (2006) 24(1):77-81. doi:10.1080/07357900500449702

5. Feinberg AP, Tycko B. The history of cancer epigenetics. Nat Rev Cancer (2004) 4(2):143-53. doi:10.1038/nrc1279

6. Hegi ME, Diserens A-C, Gorlia T, Hamou M-F, de Tribolet N, Weller M, et al. MGMT gene silencing and benefit from temozolomide in glioblastoma. $\mathrm{N}$ Engl J Med (2005) 352(10):997-1003. doi:10.1056/NEJMoa043331

7. Li B, Carey M, Workman JL. The role of chromatin during transcription. Cell (2007) 128(4):707-19. doi:10.1016/j.cell.2007.01.015

8. Hake SB, Garcia BA, Duncan EM, Kauer M, Dellaire G, Shabanowitz J, et al. Expression patterns and post-translational modifications associated with mammalian histone H3 variants. J Biol Chem (2006) 281(1):559-68. doi:10.1074/jbc.M509266200

9. Jang C-W, Shibata Y, Starmer J, Yee D, Magnuson T. Histone H3.3 maintains genome integrity during mammalian development. Genes Dev (2015) 29(13):1377-92. doi:10.1101/gad.264150.115 intratumoral genetic heterogeneity, which may protect HGGs from being fully eradicated, as well as altering the uptake and concentration of the HDAC inhibitor into the cells. Furthermore, methods are yet to be found, which allow better penetration of HDAC inhibitors through the blood-brain barrier. For example, the HDAC inhibitors panobinostat and vorinostat are substrates for the major efflux transporters at the blood-brain barrier, which may give some rationale as to why they have so far failed to translate into effective therapies in clinical trials (104). The above reasons are likely to contribute to the slow progress of clinical trials investigating HDAC inhibitor use in HGGs.

Targeting multiple epigenetic and genetic aberrations will likely be the key to succeeding in treating HGGs, and future clinical trials are needed to further explore combination therapies, alongside novel techniques to improve the penetration of the blood-brain barrier.

\section{AUTHOR CONTRIBUTIONS}

MW, WS, and KK: manuscript research and writing. SL and KM: manuscript review and revision.

\section{FUNDING}

British Neuropathological Society University of Bristol, Campaigns and Alumni Relations WGBS is a Medical Research Council Clinical Research Training Fellow joint funded between the MRC and The Brain Tumour Charity (grant reference: MR/ N00130/1).

10. Szenker E, Ray-Gallet D, Almouzni G. The double face of the histone variant H3.3. Cell Res (2011) 21(3):421-34. doi:10.1038/cr.2011.14

11. Berger SL. The complex language of chromatin regulation during transcription. Nature (2007) 447(7143):407-12. doi:10.1038/nature05915

12. Chi P, Allis CD, Wang GG. Covalent histone modifications - miswritten, misinterpreted and mis-erased in human cancers. Nat Rev Cancer (2010) 10(7):457-69. doi:10.1038/nrc2876

13. Schwartzentruber J, Korshunov A, Liu X-Y, Jones DTW, Pfaff E, Jacob K, et al. Driver mutations in histone $\mathrm{H} 3.3$ and chromatin remodelling genes in paediatric glioblastoma. Nature (2012) 482(7384):226-31. doi:10.1038/ nature 10833

14. Talbert PB, Henikoff S. Histone variants [mdash] ancient wrap artists of the epigenome. Nat Rev Mol Cell Biol (2010) 11(4):264-75. doi:10.1038/ nrm2861

15. Behjati S, Tarpey PS, Presneau N, Scheipl S, Pillay N, Van Loo P, et al. Distinct $\mathrm{H} 3 \mathrm{~F} 3 \mathrm{~A}$ and $\mathrm{H} 3 \mathrm{~F} 3 \mathrm{~B}$ driver variants define chondroblastoma and giant cell tumour of bone. Nat Genet (2013) 45(12):1479-82. doi:10.1038/ng.2814

16. Khuong-Quang D-A, Buczkowicz P, Rakopoulos P, Liu X-Y, Fontebasso AM, Bouffet E, et al. K27M mutation in histone H3.3 defines clinically and biologically distinct subgroups of pediatric diffuse intrinsic pontine gliomas. Acta Neuropathol (2012) 124(3):439-47. doi:10.1007/s00401012-0998-0

17. Bernstein BE, Mikkelsen TS, Xie X, Kamal M, Huebert DJ, Cuff J, et al. A bivalent chromatin structure marks key developmental genes in embryonic stem cells. Cell (2006) 125(2):315-26. doi:10.1016/j.cell.2006.02.041

18. Kolasinska-Zwierz P, Down T, Latorre I, Liu T, Liu XS, Ahringer J. Differential chromatin marking of introns and expressed exons by H3K36me3. Nat Genet (2009) 41(3):376-81. doi:10.1038/ng.322

19. Bjerke L, Mackay A, Nandhabalan M, Burford A, Jury A, Popov S, et al. Histone H3.3 mutations drive paediatric glioblastoma through upregulation 
of MYCN. Cancer Discov (2013) 3(5):512-9. doi:10.1158/2159-8290. CD-12-0426

20. Gielen GH, Gessi M, Hammes J, Kramm CM, Waha A, Pietsch T. H3F3A K27M mutation in pediatric CNS tumors: a marker for diffuse highgrade astrocytomas. Am J Clin Pathol (2013) 139(3):345-9. doi:10.1309/ AJCPABOHBC33FVMO

21. Wu G, Broniscer A, McEachron TA, Lu C, Paugh BS, Becksfort J, et al. Somatic histone $\mathrm{H} 3$ alterations in pediatric diffuse intrinsic pontine gliomas and non-brainstem glioblastomas. Nat Genet (2012) 44(3):251-3. doi:10.1038/ ng. 1102

22. Parsons DW, Jones S, Zhang X, Lin JC-H, Leary RJ, Angenendt P, et al. An integrated genomic analysis of human glioblastoma multiforme. Science (2008) 321(5897):1807. doi:10.1126/science.1164382

23. Sturm D, Witt H, Hovestadt V, Khuong-Quang D-A, Jones David TW, Konermann C, et al. Hotspot mutations in H3F3A and IDH1 define distinct epigenetic and biological subgroups of glioblastoma. Cancer Cell (2012) 22(4):425-37. doi:10.1016/j.ccr.2012.08.024

24. Ku M, Koche RP, Rheinbay E, Mendenhall EM, Endoh M, Mikkelsen TS, et al. Genomewide analysis of PRC1 and PRC2 occupancy identifies two classes of bivalent domains. PLoS Genet (2008) 4(10):e1000242. doi:10.1371/ journal.pgen. 1000242

25. Su IH, Dobenecker M-W, Dickinson E, Oser M, Basavaraj A, Marqueron R, et al. Polycomb group protein Ezh2 controls actin polymerization and cell signaling. Cell (2005) 121(3):425-36. doi:10.1016/j.cell.2005.02.029

26. Lewis PW, Müller MM, Koletsky MS, Cordero F, Lin S, Banaszynski LA, et al. Inhibition of PRC2 activity by a gain-of-function $\mathrm{H} 3$ mutation found in pediatric glioblastoma. Science (2013) 340(6134):857-61. doi:10.1126/ science. 1232245

27. Venneti S, Garimella MT, Sullivan LM, Martinez D, Huse JT, Heguy A, et al. Evaluation of histone 3 lysine 27 trimethylation (H3K27me3) and enhancer of zest 2 (EZH2) in pediatric glial and glioneuronal tumors shows decreased H3K27me3 in H3F3A K27M mutant glioblastomas. Brain Pathol (2013) 23(5):558-64. doi:10.1111/bpa.12042

28. Bender S, Tang Y, Lindroth Anders M, Hovestadt V, Jones David TW, Kool $\mathrm{M}$, et al. Reduced H3K27me3 and DNA hypomethylation are major drivers of gene expression in K27M mutant pediatric high-grade gliomas. Cancer Cell (2013) 24(5):660-72. doi:10.1016/j.ccr.2013.10.006

29. Chan K-M, Fang D, Gan H, Hashizume R, Yu C, Schroeder M, et al. The histone H3.3K27M mutation in pediatric glioma reprograms H3K27 methylation and gene expression. Genes Dev (2013) 27(9):985-90. doi:10.1101/ gad.217778.113

30. Fontebasso AM, Schwartzentruber J, Khuong-Quang D-A, Liu X-Y, Sturm D, Korshunov A, et al. Mutations in SETD2 and genes affecting histone H3K36 methylation target hemispheric high-grade gliomas. Acta Neuropathol (2013) 125(5):659-69. doi:10.1007/s00401-013-1095-8

31. Saratsis A, Kambhampati M, Snyder K, Yadavilli S, Devaney J, Harmon $\mathrm{B}$, et al. Comparative multidimensional molecular analyses of pediatric diffuse intrinsic pontine glioma reveals distinct molecular subtypes. Acta Neuropathol (2014) 127(6):881-95. doi:10.1007/s00401-013-1218-2

32. Swartling FJ, Savov V, Persson AI, Chen J, Hackett CS, Northcott PA, et al. Distinct neural stem cell populations give rise to disparate brain tumors in response to N-MYC. Cancer Cell (2012) 21(5):601-13. doi:10.1016/j. ccr.2012.04.012

33. Fontebasso AM, Liu X-Y, Sturm D, Jabado N. Chromatin remodeling defects in pediatric and young adult glioblastoma: a tale of a variant histone 3 tail. Brain Pathol (2013) 23(2):210-6. doi:10.1111/bpa.12023

34. Dhayalan A, Tamas R, Bock I, Tattermusch A, Dimitrova E, Kudithipudi $\mathrm{S}$, et al. The ATRX-ADD domain binds to $\mathrm{H} 3$ tail peptides and reads the combined methylation state of K4 and K9. Hum Mol Genet (2011) 20(11):2195-203. doi:10.1093/hmg/ddr107

35. Lewis PW, Elsaesser SJ, Noh K-M, Stadler SC, Allis CD. Daxx is an H3.3specific histone chaperone and cooperates with ATRX in replication-independent chromatin assembly at telomeres. Proc Natl Acad Sci U S A (2010) 107(32):14075-80. doi:10.1073/pnas.1008850107

36. Pathak P, Jha P, Purkait S, Sharma V, Suri V, Sharma MC, et al. Altered global histone-trimethylation code and H3F3A-ATRX mutation in pediatric GBM. J Neurooncol (2015) 121(3):489-97. doi:10.1007/ s11060-014-1675-z
37. Heaphy CM, de Wilde RF, Jiao Y, Klein AP, Edil BH, Shi C, et al. Altered telomeres in tumors with ATRX and DAXX mutations. Science (2011) 333(6041):425. doi:10.1126/science. 1207313

38. Lee J, Solomon DA, Tihan T. The role of histone modifications and telomere alterations in the pathogenesis of diffuse gliomas in adults and children. J Neurooncol (2017) 132(1):1-11. doi:10.1007/s11060-016-2349-9

39. Hartmann C, Meyer J, Balss J, Capper D, Mueller W, Christians A, et al. Type and frequency of IDH1 and IDH2 mutations are related to astrocytic and oligodendroglial differentiation and age: a study of 1,010 diffuse gliomas. Acta Neuropathol (2009) 118(4):469-74. doi:10.1007/s00401-009-0561-9

40. Cairns RA, Mak TW. Oncogenic isocitrate dehydrogenase mutations: mechanisms, models, and clinical opportunities. Cancer Discov (2013) 3(7):730-41. doi:10.1158/2159-8290.CD-13-0083

41. Balss J, Meyer J, Mueller W, Korshunov A, Hartmann C, von Deimling A. Analysis of the IDH1 codon 132 mutation in brain tumors. Acta Neuropathol (2008) 116(6):597-602. doi:10.1007/s00401-008-0455-2

42. Yan H, Parsons DW, Jin G, McLendon R, Rasheed BA, Yuan W, et al. IDH1 and IDH2 mutations in gliomas. N Engl J Med (2009) 360(8):765-73. doi:10.1056/NEJMoa0808710

43. Dang L, White DW, Gross S, Bennett BD, Bittinger MA, Driggers EM, et al. Cancer-associated IDH1 mutations produce 2-hydroxyglutarate. Nature (2009) 462(7274):739-44. doi:10.1038/nature08617

44. Noushmehr H, Weisenberger DJ, Diefes K, Phillips HS, Pujara K, Berman $\mathrm{BP}$, et al. Identification of a CpG island methylator phenotype that defines a distinct subgroup of glioma. Cancer Cell (2010) 17(5):510-22. doi:10.1016/j. ccr.2010.03.017

45. Lu C, Ward PS, Kapoor GS, Rohle D, Turcan S, Abdel-Wahab O, et al. IDH mutation impairs histone demethylation and results in a block to cell differentiation. Nature (2012) 483(7390):474-8. doi:10.1038/nature10860

46. Gallo M, Coutinho Fiona J, Vanner Robert J, Gayden T, Mack Stephen C, Murison A, et al. MLL5 orchestrates a cancer self-renewal state by repressing the histone variant $\mathrm{H} 3.3$ and globally reorganizing chromatin. Cancer Cell (2015) 28(6):715-29. doi:10.1016/j.ccell.2015.10.005

47. Sebastian S, Sreenivas P, Sambasivan R, Cheedipudi S, Kandalla P, Pavlath GK, et al. MLL5, a trithorax homolog, indirectly regulates H3K4 methylation, represses cyclin A2 expression, and promotes myogenic differentiation. Proc Natl Acad Sci U S A (2009) 106(12):4719-24. doi:10.1073/pnas. 0807136106

48. Turcan S, Rohle D, Goenka A, Walsh LA, Fang F, Yilmaz E, et al. IDH1 mutation is sufficient to establish the glioma hypermethylator phenotype. Nature (2012) 483(7390):479-83. doi:10.1038/nature10866

49. Xu W, Yang H, Liu Y, Yang Y, Wang P, Kim S-H, et al. Oncometabolite 2-hydroxyglutarate is a competitive inhibitor of $\alpha$-ketoglutarate-dependent dioxygenases. Cancer Cell (2011) 19(1):17-30. doi:10.1016/j.ccr.2010.12.014

50. Takai H, Masuda K, Sato T, Sakaguchi Y, Suzuki T, Suzuki T, et al. 5-hydroxymethylcytosine plays a critical role in glioblastomagenesis by recruiting the CHTOP-methylosome complex. Cell Rep (2014) 9(1):48-60. doi:10.1016/j.celrep.2014.08.071

51. Guo Junjie U, Su Y, Zhong C, Ming G-L, Song H. Hydroxylation of 5 -methylcytosine by TET1 promotes active DNA demethylation in the adult brain. Cell (2011) 145(3):423-34. doi:10.1016/j.cell.2011.03.022

52. Christensen BC, Smith AA, Zheng S, Koestler DC, Houseman EA, Marsit CJ, et al. DNA methylation, isocitrate dehydrogenase mutation, and survival in glioma. J Natl Cancer Inst (2011) 103(2):143-53. doi:10.1093/jnci/djq497

53. Nobusawa S, Watanabe T, Kleihues P, Ohgaki H. IDH1 mutations as molecular signature and predictive factor of secondary glioblastomas. Clin Cancer Res (2009) 15(19):6002-7. doi:10.1158/1078-0432.CCR-09-0715

54. Dawson Mark A, Kouzarides T. Cancer epigenetics: from mechanism to therapy. Cell (2012) 150(1):12-27. doi:10.1016/j.cell.2012.06.013

55. Khan O, La Thangue NB. HDAC inhibitors in cancer biology: emerging mechanisms and clinical applications. Immunol Cell Biol (2012) 90(1):85-94. doi:10.1038/icb.2011.100

56. Boyer LA, Latek RR, Peterson CL. The SANT domain: a unique histone-tail-binding module? Nat Rev Mol Cell Biol (2004) 5(2):158-63. doi:10.1038/nrm1314

57. Reichert N, Choukrallah M-A, Matthias P. Multiple roles of class I HDACs in proliferation, differentiation, and development. Cell Mol Life Sci (2012) 69(13):2173-87. doi:10.1007/s00018-012-0921-9 
58. Dokmanovic M, Clarke C, Marks PA. Histone deacetylase inhibitors: overview and perspectives. Mol Cancer Res (2007) 5(10):981-9. doi:10.1158/15417786.MCR-07-0324

59. Lagger G, O'Carroll D, Rembold M, Khier H, Tischler J, Weitzer G, et al. Essential function of histone deacetylase 1 in proliferation control and CDK inhibitor repression. EMBO J (2002) 21(11):2672-81. doi:10.1093/ emboj/21.11.2672

60. Xu WS, Parmigiani RB, Marks PA. Histone deacetylase inhibitors: molecular mechanisms of action. Oncogene (2007) 26(37):5541-52. doi:10.1038/ sj.onc. 1210620

61. Zhang CL, McKinsey TA, Chang S, Antos CL, Hill JA, Olson EN. Class II histone deacetylases act as signal-responsive repressors of cardiac hypertrophy. Cell (2002) 110(4):479-88. doi:10.1016/S0092-8674(02)00861-9

62. Nagarajan RP, CostelloJF. Epigenetic mechanisms in glioblastoma multiforme. Semin Cancer Biol (2009) 19(3):188-97. doi:10.1016/j.semcancer.2009.02.005

63. Bezecny P. Histone deacetylase inhibitors in glioblastoma: pre-clinical and clinical experience. Med Oncol (2014) 31(6):1-15. doi:10.1007/ s12032-014-0985-5

64. Brennan CW, Verhaak RGW, McKenna A, Campos B, Noushmehr H, Salama SR, et al. The somatic genomic landscape of glioblastoma. Cell (2013) 155(2):462-77. doi:10.1016/j.cell.2013.09.034

65. Lucio-Eterovic AKB, Cortez MAA, Valera ET, Motta FJN, Queiroz RGP, Machado HR, et al. Differential expression of 12 histone deacetylase (HDAC) genes in astrocytomas and normal brain tissue: class II and IV are hypoexpressed in glioblastomas. BMC Cancer (2008) 8:243. doi:10.1186/1471-2407-8-243

66. Weichert W. HDAC expression and clinical prognosis in human malignancies. Cancer Lett (2009) 280(2):168-76. doi:10.1016/j.canlet.2008.10.047

67. Kim YZ. Altered histone modifications in gliomas. Brain Tumor Res Treat (2014) 2(1):7-21. doi:10.14791/btrt.2014.2.1.7

68. Osada H, Tatematsu Y, Saito H, Yatabe Y, Mitsudomi T, Takahashi T. Reduced expression of class II histone deacetylase genes is associated with poor prognosis in lung cancer patients. Int J Cancer (2004) 112(1):26-32. doi:10.1002/ ijc. 20395

69. Fouladi M, Park JR, Stewart CF, Gilbertson RJ, Schaiquevich P, Sun J, et al. Pediatric phase I trial and pharmacokinetic study of vorinostat: a children's oncology group phase I consortium report. J Clin Oncol (2010) 28(22):36239. doi:10.1200/JCO.2009.25.9119

70. Hummel TR, Wagner L, Ahern C, Fouladi M, Reid JM, McGovern RM, et al. A pediatric phase 1 trial of vorinostat and temozolomide in relapsed or refractory primary brain or spinal cord tumors: a Children's Oncology Group Phase 1 Consortium Study. Pediatr Blood Cancer (2013) 60(9):1452-7. doi:10.1002/pbc. 24541

71. Institute. NC. Vorinostat, Temozolomide, and Radiation Therapy in Treating Patients with Newly Diagnosed Glioblastoma Multiforme. Bethesda, MD: National Library of Medicine (2000). Available from: https://clinicaltrials. gov/ct2/show/NCT00731731

72. Muscal JA, Thompson PA, Horton TM, Ingle AM, Ahern CH, McGovern $\mathrm{RM}$, et al. A phase I trial of vorinostat and bortezomib in children with refractory or recurrent solid tumors: a Children's Oncology Group Phase I Consortium Study (ADVL0916). Pediatr Blood Cancer (2013) 60(3):390-5. doi: $10.1002 / p b c .24271$

73. Su JM, Li X-N, Thompson P, Ou C-N, Ingle AM, Russell H, et al. Phase 1 study of valproic acid in pediatric patients with refractory solid or CNS tumors: a children's oncology group report. Clin Cancer Res (2011) 17(3):589-97. doi:10.1158/1078-0432.CCR-10-0738

74. Jack Su BCoM. Valproic Acid and Radiation Followed by Maintenance Valproic Acid and Bevacizumab in Children with High Grade Gliomas or Diffuse Intrinsic Pontine Glioma. Bethesda, MD: National Library of Medicine (2000). Available from: https://clinicaltrials.gov/show/NCT00879437

75. NCI. Vorinostat, Temozolomide, or Bevacizumab in Combination with Radiation Therapy Followed by Bevacizumab and Temozolomide in Young Patients with Newly Diagnosed High-Grade Glioma. Bethesda, MD: National Library of Medicine (2000). Available from: https://clinicaltrials.gov/ct2/ show/NCT01236560

76. Galanis E, Jaeckle KA, Maurer MJ, Reid JM, Ames MM, Hardwick JS, et al. Phase II trial of vorinostat in recurrent glioblastoma multiforme: a North Central Cancer Treatment Group Study. J Clin Oncol (2009) 27(12):2052-8. doi:10.1200/JCO.2008.19.0694
77. Friday BB, Anderson SK, Buckner J, Yu C, Giannini C, Geoffroy F, et al. Phase II trial of vorinostat in combination with bortezomib in recurrent glioblastoma: a North Central Cancer Treatment Group Study. Neuro Oncol (2012) 14(2):215-21. doi:10.1093/neuonc/nor 198

78. Iwamoto FM, Lamborn KR, Kuhn JG, Wen PY, Alfred Yung WK, Gilbert MR, et al. A phase I/II trial of the histone deacetylase inhibitor romidepsin for adults with recurrent malignant glioma: North American Brain Tumor Consortium Study 03-03. Neuro Oncol (2011) 13(5):509-16. doi:10.1093/ neuonc/nor017

79. Drappatz J, Lee EQ, Hammond S, Grimm SA, Norden AD, Beroukhim R, et al. Phase I study of panobinostat in combination with bevacizumab for recurrent high-grade glioma. J Neurooncol (2012) 107(1):133-8. doi:10.1007/ s11060-011-0717-z

80. Lee EQ, Reardon DA, Schiff D, Drappatz J, Muzikansky A, Grimm SA, et al. Phase II study of panobinostat in combination with bevacizumab for recurrent glioblastoma and anaplastic glioma. Neuro Oncol (2015) 17(6):862-7. doi:10.1093/neuonc/nou350

81. Shi W, Werner-Wasik M, Andrews DW, Evans JJ, Glass J, Kim L, et al. Phase I trial of panobinostat and fractionated stereotactic re-irradiation therapy for recurrent high grade gliomas. J Neurooncol (2016) 127(3):535-9. doi:10.1007/ s11060-016-2059-3

82. Krauze AV, Myrehaug SD, Chang MG, Holdford DJ, Smith S, Shih J, et al. A phase 2 study of concurrent radiation therapy, temozolomide, and the histone deacetylase inhibitor valproic acid for patients with glioblastoma. Int J Radiat Oncol Biol Phys (2015) 92(5):986-92. doi:10.1016/j.ijrobp. 2015.04.038

83. Brown PD, Krishnan S, Sarkaria JN, Wu W, Jaeckle KA, Uhm JH, et al. Phase I/II trial of erlotinib and temozolomide with radiation therapy in the treatment of newly diagnosed glioblastoma multiforme: North Central Cancer Treatment Group Study N0177. J Clin Oncol (2008) 26(34):5603-9. doi:10.1200/JCO.2008.18.0612

84. Peereboom D, Shepard D, Ahluwalia M, Brewer C, Agarwal N, Stevens GJ, et al. Phase II trial of erlotinib with temozolomide and radiation in patients with newly diagnosed glioblastoma multiforme. J Neurooncol (2010) 98(1):93-9. doi:10.1007/s11060-009-0067-2

85. Prados MD, Chang SM, Butowski N, DeBoer R, Parvataneni R, Carliner $\mathrm{H}$, et al. Phase II study of erlotinib plus temozolomide during and after radiation therapy in patients with newly diagnosed glioblastoma multiforme or gliosarcoma. J Clin Oncol (2009) 27(4):579-84. doi:10.1200/JCO.2008. 18.9639

86. Rosenfeld MR, Chamberlain MC, Grossman SA, Peereboom DM, Lesser GJ, Batchelor TT, et al. A multi-institution phase II study of poly-ICLC and radiotherapy with concurrent and adjuvant temozolomide in adults with newly diagnosed glioblastoma. Neuro Oncol (2010) 12(10):1071-7. doi:10.1093/neuonc/noq071

87. Butowski N, Chang SM, Lamborn KR, Polley MY, Pieper R, Costello JF, et al. Phase II and pharmacogenomics study of enzastaurin plus temozolomide during and following radiation therapy in patients with newly diagnosed glioblastoma multiforme and gliosarcoma. Neuro Oncol (2011) 13(12):13318. doi:10.1093/neuonc/nor130

88. Weller M, Gorlia T, Cairncross JG, van den Bent MJ, Mason W, Belanger $\mathrm{K}$, et al. Prolonged survival with valproic acid use in the EORTC/NCIC temozolomide trial for glioblastoma. Neurology (2011) 77(12):1156-64. doi:10.1212/WNL.0b013e31822f02el

89. Peters KB, Vredenburgh JJ, Desjardins A, Friedman HS, Herndon JE, Coan $\mathrm{AD}$, et al. Vorinostat, temozolomide, and bevacizumab for patients with recurrent glioblastoma: a phase I/II trial. JClin Oncol (2012) 30(Suppl): abstr 2027.

90. H. Lee Moffitt Cancer Center and Research Institute. A Phase I Trial of Vorinostat in Combination with Bevacizumab \& Irinotecan in Recurrent Glioblastoma. Bethesda, MD: National Library of Medicine (2000). Available from: https://clinicaltrials.gov/ct2/show/NCT00762255

91. NCI. Vorinostat Combined with Isotretinoin and Chemotherapy in Treating Younger Patients with Embryonal Tumors of the Central Nervous System. Bethesda, MD: National Library of Medicine (2000). Available from: https:// clinicaltrials.gov/ct2/show/NCT00867178

92. Lee EQ, Puduvalli VK, Reid JM, Kuhn JG, Lamborn KR, Cloughesy TF, et al. Phase I study of vorinostat in combination with temozolomide in patients with high-grade gliomas: North American Brain Tumor Consortium Study 
04-03. Clin Cancer Res (2012) 18(21):6032-9. doi:10.1158/1078-0432. CCR-12-1841

93. Hashizume R, Andor N, Ihara Y, Lerner R, Gan H, Chen X, et al. Pharmacologic inhibition of histone demethylation as a therapy for pediatric brainstem glioma. Nat Med (2014) 20(12):1394-6. doi:10.1038/ nm. 3716

94. Morales La Madrid A, Hashizume R, Kieran MW. Future clinical trials in DIPG: bringing epigenetics to the clinic. Front Oncol (2015) 5:148. doi:10.3389/fonc.2015.00148

95. Grasso CS, Tang Y, Truffaux N, Berlow NE, Liu L, Debily M-A, et al. Functionally defined therapeutic targets in diffuse intrinsic pontine glioma. Nat Med (2015) 21(6):555-9. doi:10.1038/ nm0715-827a

96. Sparmann A, van Lohuizen M. Polycomb silencers control cell fate, development and cancer. Nat Rev Cancer (2006) 6(11):846-56. doi:10.1038/ nrc1991

97. Ciarapica R, Carcarino E, Adesso L, De Salvo M, Bracaglia G, Leoncini $\mathrm{PP}$, et al. Pharmacological inhibition of EZH2 as a promising differentiation therapy in embryonal RMS. BMC Cancer (2014) 14(1):139. doi:10.1186/1471-2407-14-139

98. Kleer CG, Cao Q, Varambally S, Shen R, Ota I, Tomlins SA, et al. EZH2 is a marker of aggressive breast cancer and promotes neoplastic transformation of breast epithelial cells. Proc Natl Acad Sci U S A (2003) 100(20):11606-11. doi:10.1073/pnas.1933744100

99. Varambally S, Dhanasekaran SM, Zhou M, Barrette TR, Kumar-Sinha C, Sanda MG, et al. The polycomb group protein EZH2 is involved in progression of prostate cancer. Nature (2002) 419:624-9. doi:10.1038/ nature 01075

100. Sneeringer CJ, Scott MP, Kuntz KW, Knutson SK, Pollock RM, Richon $\mathrm{VM}$, et al. Coordinated activities of wild-type plus mutant EZH2 drive tumor-associated hypertrimethylation of lysine 27 on histone $\mathrm{H} 3$ (H3K27) in human B-cell lymphomas. Proc Natl Acad Sci U S A (2010) 107(49):20980-5. doi:10.1073/pnas.1012525107

101. Liu B-L, Cheng J-X, Zhang X, Wang R, Zhang W, Lin H, et al. Global histone modification patterns as prognostic markers to classify glioma patients. Cancer Epidemiol Biomarkers Prev (2010) 19(11):2888. doi:10.1158/10559965.EPI-10-0454

102. Taylor KR, Mackay A, Truffaux N, Butterfield YS, Morozova O, Philippe C, et al. Recurrent activating ACVR1 mutations in diffuse intrinsic pontine glioma. Nat Genet (2014) 46(5):457-61. doi:10.1038/ng.2925

103. Kaplan FS, Xu M, Seemann P, Connor M, Glaser DL, Carroll L, et al. Classic and atypical FOP phenotypes are caused by mutations in the BMP type I receptor ACVR1. Hum Mutat (2009) 30(3):379-90. doi:10.1002/ humu. 20868

104. Veringa SJE, Biesmans D, van Vuurden DG, Jansen MHA, Wedekind LE, Horsman I, et al. In vitro drug response and efflux transporters associated with drug resistance in pediatric high grade glioma and diffuse intrinsic pontine glioma. PLoS One (2013) 8(4):e61512. doi:10.1371/journal.pone. 0061512

Conflict of Interest Statement: The authors declare that the research was conducted in the absence of any commercial or financial relationships that could be construed as a potential conflict of interest.

Copyright $\odot 2017$ Williams, Singleton, Lowis, Malik and Kurian. This is an open-access article distributed under the terms of the Creative Commons Attribution License (CC BY). The use, distribution or reproduction in other forums is permitted, provided the original author $(s)$ or licensor are credited and that the original publication in this journal is cited, in accordance with accepted academic practice. No use, distribution or reproduction is permitted which does not comply with these terms. 